\title{
Characterization of DAHP Synthase L183Q Mutation Comparison to Wild One by Prokaryotic Expression System
}

\author{
Hansong Yu,Tian Hao, Yuhua Wang,Chunhong Piao,Junmei Liu and Yaohui Hu \\ College of Food Science and Engineering \\ JiLin Agriclutural University \\ Changchun, 130118,China \\ e-mail: yuhansong@163.com
}

\begin{abstract}
The prokaryotic expression system was employed in order to compare the catalytic properties of $\mathbf{L 1 8 3 Q}$ mutation and wild DAHP synthase enzyme. The gene of L183Q mutation and wild DAHP synthase enzyme was cloned and expressed by pET vector system and Eco.li BL21. The specific activity of the two recombinant enzyme was determinated. The result show that the relative activity of wild and L183Q mutation is $2.4 \mathrm{u} / \mathrm{mg}$ and $3.6 \mathrm{u} / \mathrm{mg}$, respectively. But the optimal $\mathrm{pH}$ and temperature difference between wild and mutation DAHP synthase enzyme is not significant ( $p>0.05)$.
\end{abstract}

Keywords-DAHP synthase; Catalytic properties; Recombinant key enzyme of amino acid synthesize

\section{INTRODUCTION}

DS enzyme (DAHP synthase: 3-Deoxy-Darabinoheptulosonate 7-phosphate synthase) is the first key enzyme in aromatic amino acids metabolic pathway, the rate-limiting enzyme as well. Improve the expression of the enzyme is beneficial to increasing the flow of aromatic amino acid metabolism. It is an effective method to obtain high activity enzyme by mutation and mutant enzyme gene recombination and increase the amount of enzyme expression. Therefore, our research group has been engaged in obtaining higher active DS mutant enzyme by site-directed mutagenesis. And high yield tryptophan engineering bacteria was got by the method of gene substitution and over-expression of mutant DS enzyme.

Currently most research are focus on E.coli DS enzyme at home and abroad. But a few studies major in industrial amino acid-producing strains Corynebacterium glutamicum DS synthase. It has not been reported that the enzyme mutations and gene substitution.

Therefore, wild and mutation DS enzyme was cloned and expressed by prokaryotic expression system in this study. Then the recombinant enzyme catalytic properties was studied, which provided the basic theory for gene modification on industrial tryptophan producing strains.

\section{MATERIALS AND METHODS}

\section{A. Materials}

E.coli BL21, pET-28a (+) prokaryotic expression vector is provided by biochemical engineering laboratory, College of Food Science and Engineering, Jilin Agricultural University.

\section{B. Methods}

1) Two recombinant vector construction of wildtype and mutation DS enzyme

Construction of wild type and mutation DS enzyme vector was shown in Figure 1, the process involved in the wild-type and mutation DS gene (AroI / AroI *) cloning vector, restriction endonuclease digestion and target gene connecting with plasmid. The traditional protocol such as recombinant plasmid extraction, competent cell preparation and transformation, positive clones screen is according to the Literature [3] and Molecular cloning: a laboratory manual (Third Edition) [4]. Send the positive recombinant plasmid to Shanghai SANGON Biological Engineering Technology Service Co Ltd for sequencing, The two vectors were named pET-28a $(+)$-AroI and pET$28 \mathrm{a}(+)$-AroI $*$ which is proved to be correct. 


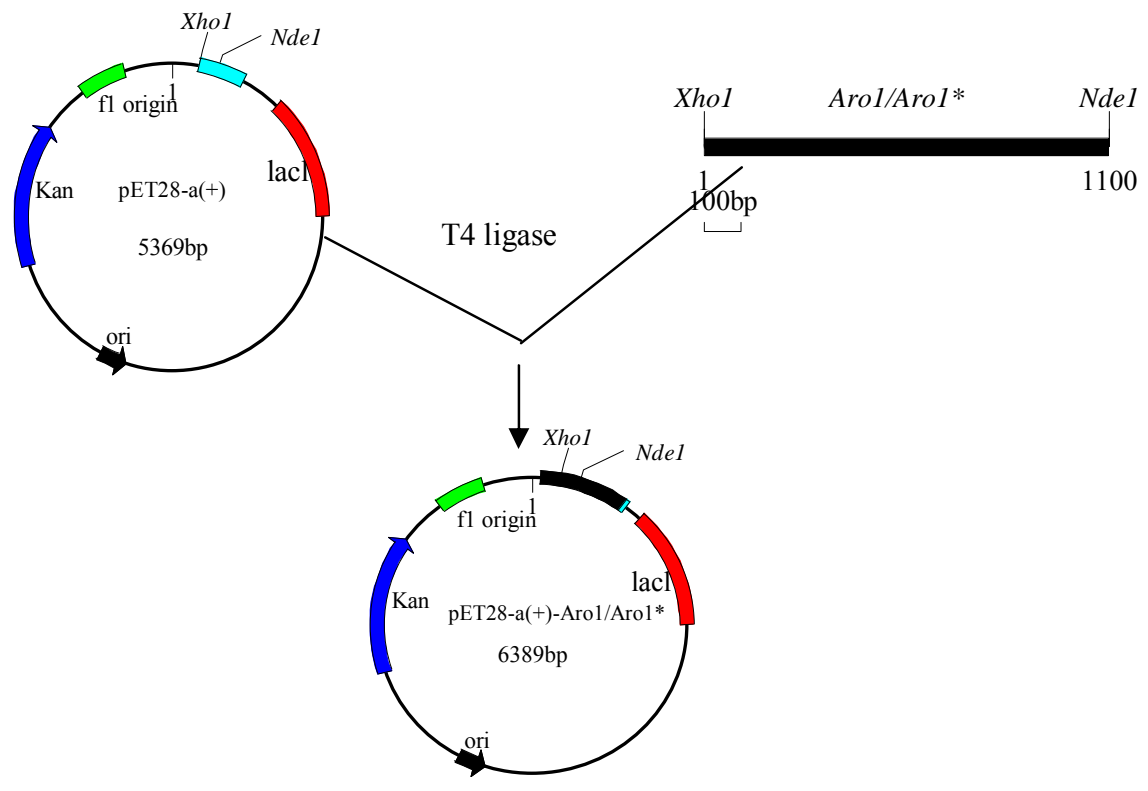

Fig.1. Construction of pET-28a(+)-Aro I and pET-28a(+)-Aro I *

2) Crude enzyme preparation of recombinant wild and mutation DS enzyme

Add the overnight cultures containing expression vector pET-28a $(+)$-AroI and pET-28a $(+)$-AroI* of E.coli BL21 $1.2 \mathrm{ml}$ into the $250 \mathrm{ml}$ flask containing 100 $\mathrm{ml} \mathrm{LB}$ liquid medium with Kan $(60 \mathrm{mg} / \mathrm{L})$, shake at $37{ }^{\circ} \mathrm{C}, 200 \mathrm{rpm}$ until $\mathrm{OD}_{600}$ approximately equal to 0.6 . Adding IPTG to the culture until its concentration is $1.0 \mathrm{mM}$,respectively. Continue shaking at $30{ }^{\circ} \mathrm{C}, 200 \mathrm{rpm}$ and $8000 \mathrm{~g}$ centrifugate $5 \mathrm{~min}$ to collecting the bacteria $5 \mathrm{~h}$ later. The cell was suspended in $50 \mathrm{ml}$ sodium phosphate buffer which containing $0.2 \mathrm{mg} / \mathrm{ml}$ lysozyme and $10 \mathrm{mM}$ DTT $(20 \mathrm{mM}, \mathrm{pH} 7.2)$. Then repeated freezing and thawing for 4 times following broken by ultrasonic $(10 \mathrm{~s}$, $10 \mathrm{~s}$ clearance, 30 cycles $600 \mathrm{~W}$, power). The crushed sample was collected in $13000 \mathrm{~g}, 4^{\circ} \mathrm{C}$ centrifuge for 10 min, the supernatant is crude enzyme liquid.

3) Analysis of recombinant wild type and mutation DS enzyme by SDS-PAGE and Western blotting

The crude enzyme solution prepared in 1.2.2 was analysed by SDS-PAGE, while the crude enzyme from no induced E.coli BL21 as a negative control.

SDS-polyacrylamide gel electrophoresis method are as follows: Stacking gel $4 \%$, separating gel $12.5 \%$. The equal volume of $2 \times$ SDS-PAGE sample treating liquid (6\% $\beta$ - mercaptoethanol; $6 \%$ SDS; $0.6 \%$ bromophenol blue; $20 \%$ glycerol) was added to protein sample, cooking in boiling water bath for 5min, $10000 \mathrm{~g}$ centrifugation for $3 \mathrm{~min}$ and keep the supernatant of the sample. Constant Voltage(200V) for 180 minutes Stain with Coomassie brilliant blue R-250.

After electrophoresis the proteins were transfered to nitrocellulose membrane ( $\mathrm{NC}$ membrane), closed 2 hours by blocking solution at room temperature, washing the membrane 3 times for $10 \mathrm{~min}$ each time. The 1:1000 dilution monoclonal antibody of mouse anti $6 \times$ His was added and kept at room temperature overnight. Wash the membrane again, and then the secondary antibody of goat anti rat IgG labeled with HRP (1:500 diluted) was added, wash the membrane again, finally analysed by DAB substrate solution.

4) Characterization and comparison of Recombinant Wild DS and Mutation DS Enzyme

After mixing the $1 \mathrm{ml} 10 \mathrm{mM}$ phosphate buffer $(\mathrm{pH}$ $6.8), 100 \mu 15 \mathrm{mM}$ erythritol-4-phosphate and $50 \mu 110$ $\mathrm{mM}$ Phosphoenolpyruvic acid, keeping them in $37{ }^{\circ} \mathrm{C}$ water bath for $10 \mathrm{~min}$; then add $1 \mu 10.1 \mathrm{M} \mathrm{CoCI}_{2}$ and $200 \mu 1$ crude enzyme, $37{ }^{\circ} \mathrm{C}$ water bath for $30 \mathrm{~min}$, terminate the reaction by adding $0.4 \mathrm{ml} 100 \mathrm{~g} / \mathrm{L}$ three chloroacetic acid. Then 10000rpm centrifuge for $5 \mathrm{~min}$, mix $0.25 \mathrm{ml}$ supernatant and an equal volume of $0.025 \mathrm{M}$ Periodate solution completely, reaction temperature of $25{ }^{\circ} \mathrm{C}$ and $45 \mathrm{~min}$, then adding $0.5 \mathrm{ml} 20 \mathrm{~g} / \mathrm{L}$ sodium arsenite solution, $25^{\circ} \mathrm{C}$ for $45 \mathrm{~min}$. Add the thiobarbituric solution $0.5 \mathrm{ml}(20 \mathrm{~g} / \mathrm{L}), 25^{\circ} \mathrm{C}$ for $2 \mathrm{~min}$. Thiobarbituric solution $(2 \mathrm{ml} 3 \mathrm{~g} / \mathrm{L})$ was added at last. Transfer to boiling water bath for $5 \mathrm{~min}$, removing the insoluble material by centrifugation, measuring at $\mathrm{OD}_{549}$.

\section{RESULTS AND ANALYSIS}

1) Construction and identification of recombinant expression vector pET-28a (+) pET-28a (+) -Aro I and AroI*

The possible positive clones were identified by PCR method as shown in figure 2 . A $1.1 \mathrm{~Kb}$ band could be seen from the agrose gel electrophoretic picture which consistent with the expected result. It was found that the two vector include the right open reading frame after they were sequenced. The two new plasmid was named pET28a (+)-AroI and pET-28a (+)-AroI* 


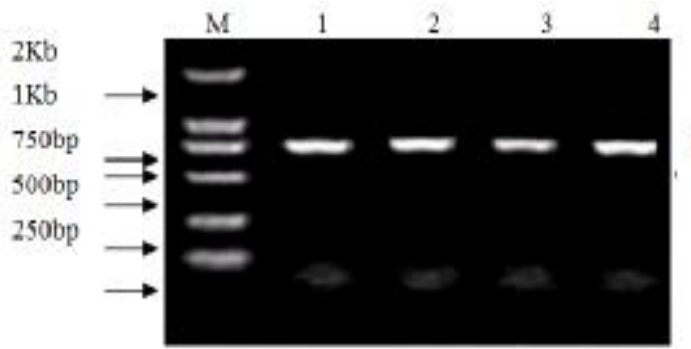

Fig. 2.Agrose gel electrophoretic of PCR product. M:DL2000;1-2:Amplified Aro I fragment; 3-4 Amplified AroI* fragment.

2) Result of recombinant wild type and mutation $D S$ enzyme by SDS-PAGE and Western blotting

The figure 3 show that the induction E.coli BL21 (DE3) which include pET-28a (+) -Aro I and pET-28a (+) -Aro I *express a specific protein with relative molecular mass about $45 \mathrm{KDa}$ compare to the control. The relative molecular mass which consistent with the theory data. The Western blotting result show that the $45 \mathrm{kDa}$ protein specific react with anti-mouse His monoclonal antibody, which proved to be that fusion expression was happened in E.coli BL21 (DE3) between Aro I/ Aro I* and expression vector.

3) Comparison thecatalytic activities between recombinant wild type and mutant $D S$ enzyme

The result of catalytic activities recombinant wild type and mutant DS enzyme shows that the mutant DS recombinant (L183Q) make the catalytic activity on E4P and PEP synthesis of DAHP increase nearly 1.5 times, comparing with the recombinant wild type DS enzyme without mutation, the most suitable $\mathrm{pH}$ value $(\mathrm{pH}=6.5)$ and optimum temperature $\left(30^{\circ} \mathrm{C}\right)$ do not change obviously.( Figure 4 and figure 5).

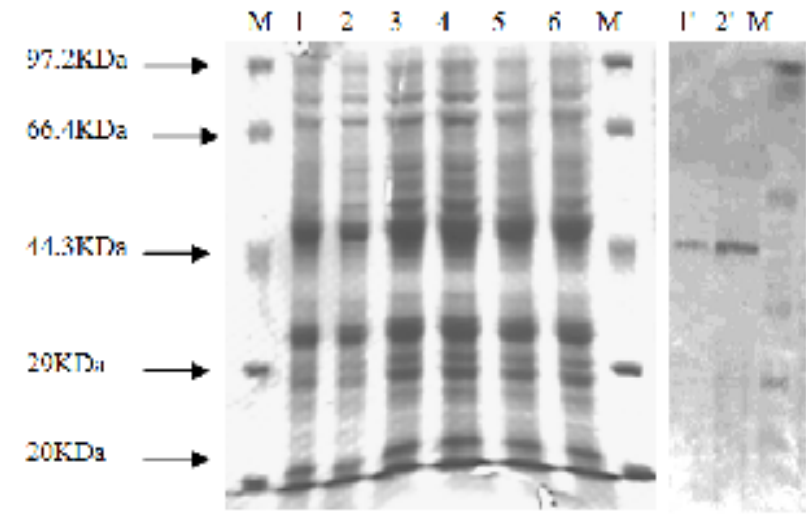

Fig. 3 SDS-PAGE profile of expressed protein induced by IPTG and characteration by Western blotting

M: protein marker; 1-2: uninduction recombinant plasmid; 3-4: pET-28a(+)-Aro I induced by IPTG;5-6: pET-28a(+)-Aro I * induced by IPTG; 1': Western blotting result of pET-28a(+)Aro I induced by IPTG;2': Western blotting result of pET$28 \mathrm{a}(+)$-Aro I * induced by IPTG.
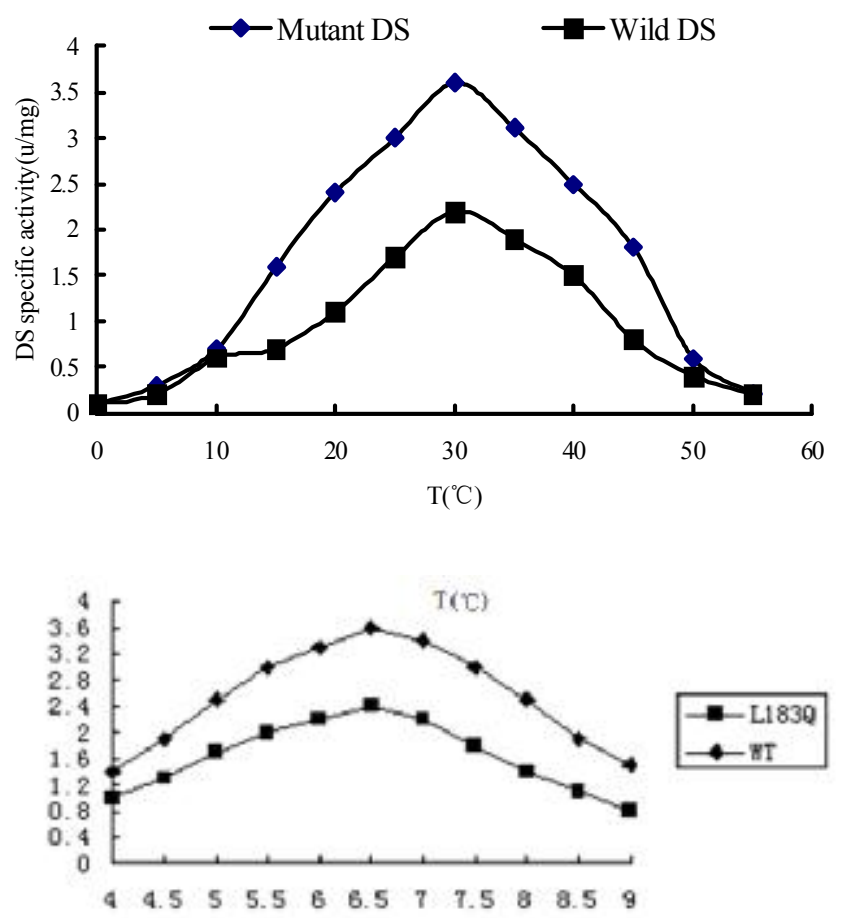

Fig. 5 Effect of $\mathrm{pH}$ on DAHP synthase specific activity of both WT and mutant.

\section{DISCUSSION}

In bacteria and plants, shikimate pathway and three specific ways synthesize three kinds of aromatic amino acids: tryptophan, tyrosine and phenylalanine respectively. The first step reaction of shikimate pathway is considered to be the rate-limiting step in Aromatic amino acid synthesis reaction, catalyzed by DS Synthase ${ }^{[5]}$. Therefore, improving the catalytic activity of DS Synthase will be important for increasing the metabolic flux of Tryptophan and other aromatic amino acids synthesis.

\section{CONCLUSION}

The wild AroI gene of Corynebacterium glutamicum LG-332 strain and the mutant gene AroI * were successfully cloned to $\mathrm{pET}-28 \mathrm{a}(+)$ prokaryotic expression vector, and that constructed prokaryotic expression vector pET-28a(+)-AroI and pET-28a(+)-AroI*, and transformed into E.coli BL21 (DE3). The over-expression product was analysed by SDS-PAGE and Western blotting and the rusult were consistent with the theoretical data. It proved that the gene achieved heterologous fusion protein with soluble form. The expressed activities of BL21/pET$28 \mathrm{a}(+)-A r o I$ and BL21/pET-28a(+)-AroI* are $2.4 \mathrm{u} / \mathrm{mg}$ and $3.6 \mathrm{u} / \mathrm{mg}$, the activity increased 1.5 -fold, and the expression of mutant DS enzyme optimum $\mathrm{pH}$ and optimum temperature did not change significantly.

\section{ACKNOWLEDGEMENT}

The authors would like to thank the Specialized Research Fund for the Doctoral Program of Higher Education "Effect of directed evolution to improve DS activity on metabolic flux of tryptophan in Corynebacterium glutamicum (20092223110002)" for the support. 


\section{REFERENCES}

[1] Deleo A B, Sprinson D B. 3-Deoxy-D-arabino-heptulosonic acid 7phosphate synthase mutants of Salmonella typhimurium.[J]. J Bacteriol. 1975, 124(3): 1312-1320.

[2] ZHANG Chunhua, ZHAO Zhi, ZHANG Yingzi, et al. Cloning, expression and sequence analysis of DS I gene in Corynebacterium pekinense AS1.299 and PD-67[J]. Acta Microbiologica Sinica. 2008(11): 1466-1472.
[3] YU Hansong,WANG Yuhua, HU Yaohui et al.. Cloning and Sitespecific Mutagenesis of DS Enzyme Gene of Corynebacterium glutamicum [J] Chinese sciencepaper Online(In Chinese)

[4] J. Sambrook and D.W. Russell. Molecular Cloning: A Laboratory Manual (Translated by HUANG Pei-tang et al). Beijing: Science Press, 2002.

[5] FAN Changsheng ZENG Xiaobing CHAI Yunrong et al.. Expression of genes aroG and pheA in phenylalanine biosynthesis[J]. Acta $\begin{array}{lll}\text { Microbiologica } & \text { Sinica } & \text { 1999(05): }\end{array}$ 